\title{
Structural and Mechanistic Insights into the Tropism of Epstein-Barr Virus
}

\author{
Britta S. Möhl', Jia Chen', Karthik Sathiyamoorthy', Theodore S. Jardetzky', and Richard Longnecker', *
}

\begin{abstract}
Epstein-Barr virus (EBV) is the prototypical $\gamma$-herpesvirus and an obligate human pathogen that infects mainly epithelial cells and B cells, which can result in malignancies. $E B V$ infects these target cells by fusing with the viral and cellular lipid bilayer membranes using multiple viral factors and host receptor(s) thus exhibiting a unique complexity in its entry machinery. To enter epithelial cells, EBV requires minimally the conserved core fusion machinery comprised of the glycoproteins $\mathrm{gH} / \mathrm{gL}$ acting as the receptor-binding complex and $g B$ as the fusogen. EBV can enter $B$ cells using gp42, which binds tightly to $\mathrm{gH} / \mathrm{gL}$ and interacts with host HLA class II, activating fusion. Previously, we published the individual crystal structures of EBV entry factors, such as $g H / g L$ and gp42, the EBV/host receptor complex, gp42/HLA-DR1, and the fusion protein EBV $g B$ in a postfusion conformation, which allowed us to identify structural determinants and regions critical for receptorbinding and membrane fusion. Recently, we reported different low resolution models of the EBV B cell entry triggering complex (gHgL/gp42/HLA class II) in "open" and "closed" states based on negative-stain single particle electron microscopy, which provide further mechanistic insights. This review summarizes the current knowledge of these key players in EBV entry and how their structures impact receptor-binding and the triggering of $g B$-mediated fusion.
\end{abstract}

\section{INTRODUCTION}

Included in the nine members of the Herpesviridae that infect humans is Epstein-Barr virus (EBV), which causes infectious mononucleosis in adolescents and the vast majority of humans have a lifelong persistent latent infection. Establishment of lifelong persistence is a hallmark of herpesvirus infections that can be associated with serious disease such as malignancies of $B$ lymphocytes, as in Burkitt and Hodgkin lymphoma, or epithelial

${ }^{1}$ Department of Microbiology and Immunology, The Feinberg School of Medicine, Northwestern University, Chicago, Illinois, USA, ${ }^{2}$ Department of Structural Biology, Stanford University School of Medicine, Stanford, California, USA

${ }^{*}$ Correspondence: r-longnecker@northwestern.edu

Received 23 March, 2016; accepted 26 March, 2016; published online 6 April, 2016

Keywords: entry, Epstein-Barr virus, fusion, herpesvirus, tropism cells, such as nasopharyngeal carcinoma and certain gastric carcinomas. However, EBV is also associated with T/natural killer-cell lymphoproliferative disorders and a variety of lymphoproliferative disorders observed in immunosuppressed individuals such as post-transplant or HIV/AIDS patients (Longnecker et al., 2013).

Herpesviruses feature approximately a dozen envelopeglycoproteins, but the conserved core fusion machinery consists of three key players - glycoprotein B (gB) and the heterodimeric complex $\mathrm{gH} / \mathrm{gL}$ accompanied by additional non-conserved receptor-binding proteins. While the highly-conserved fusion machinery indicates that these proteins function with a similar mechanism during herpesvirus fusion, the receptor-binding proteins are virusand host cell type-specific. The receptor-binding proteins include $\mathrm{gD}$ for $\alpha$-herpesvirinae (except varicella-zoster virus VZV), gO or UL128/130/131A for cytomegalovirus ( $\beta$-herpesvirus) and its functional homolog gp42 for EBV ( $\gamma$-herpesvirus), establishing the distinct cell tropism of individual herpesviruses (Adler, 2015; Spear and Longnecker, 2003). The purpose of this review is to summarize the state of the research about the entry routes utilized by EBV to mediate fusion of the virion envelope with a cellular membrane focusing on the key players and how their structure imparts receptor-binding and fusion function during herpesvirus entry. We also compare the entry mechanism of EBV to of other members of the Herpesviridae family.

\section{EPSTEIN-BARR VIRUS FUSION AND ENTRY}

Although entry is executed by the conserved core fusion machinery, herpesviruses utilize a variety of different entry routes. EBV entry is a prime example since it enters epithelial cells by direct fusion with the plasma membrane but must be endocytosed prior to membrane fusion for B cell infection (Miller and Hutt-Fletcher, 1992; Nemerow and Cooper, 1984). EBV utilizes five glycoproteins for efficient $B$ cell entry, which includes the attachment protein gp350/220, the receptor-binding protein gp42 and the core fusion machinery $\mathrm{gH} / \mathrm{gL}$ and $\mathrm{gB}$. In contrast, for epithelial cell infection the attachment proteins gp350/220 and/or BMRF2 are all that is required to complement the core fusion machinery (Longnecker et al., 2013). The abundant glycoprotein gp350/220 binds complement receptor 2 (CR2/CD21) or CD35, alternatively tethering EBV to its host cells in an attachment step that is not essential for entry but increases the efficiency of infection, similar to herpes simplex virus (HSV) gC (Janz et al., 2000; Langeland et al., 1990; Ogembo et al., 2013). The multispan membrane protein BMRF2 is thought to bind integrin $\alpha 5 \beta 1$, tethering EBV to polarized epi- 


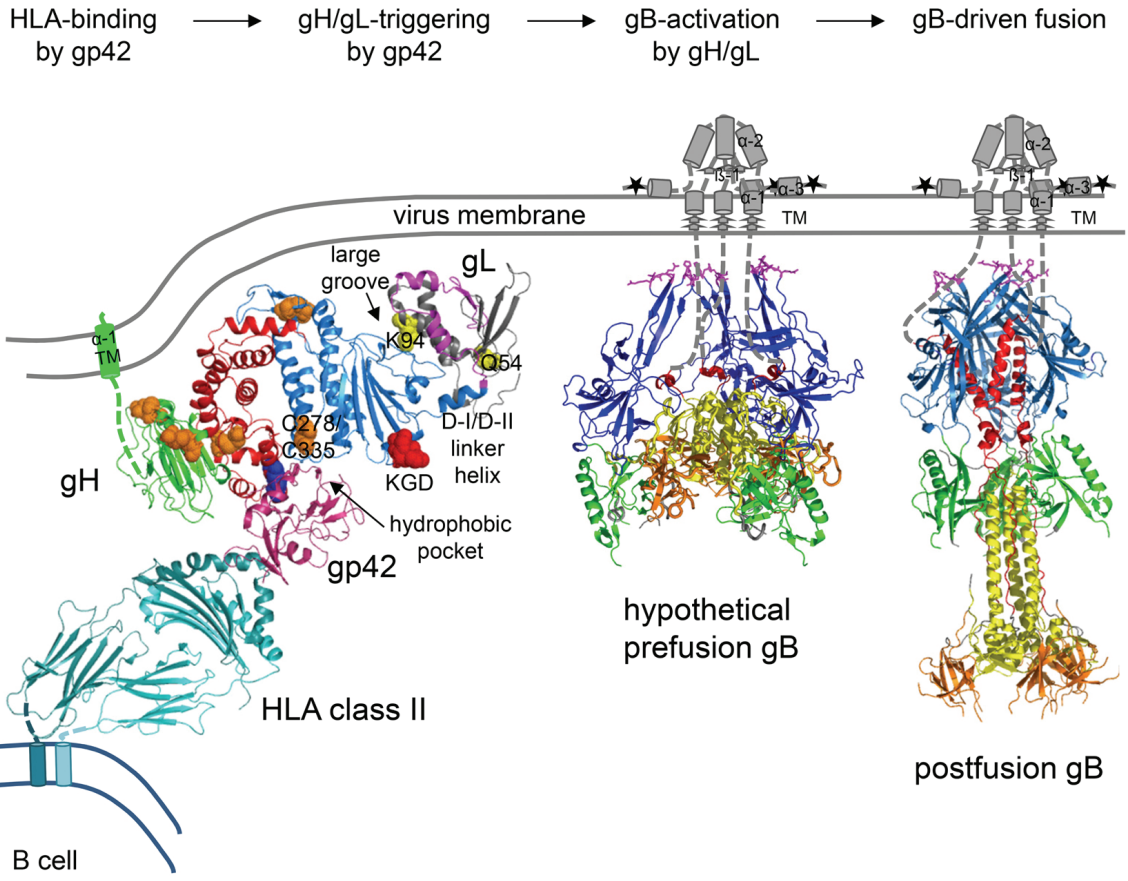

Fig. 1. Model of EBV entry into $B$ lymphocytes. First, gp42 binds to its B lymphocyte receptor HLA class II, which cause a widening of the hydrophobic pocket within gp42. The conformational change within gp42 might be transmitted to $\mathrm{gH} / \mathrm{gL}$, which allows the interaction with the fusogen $\mathrm{gB}$. In this model, D-I of $\mathrm{gH} / \mathrm{gL}$ includes the residues Q54/K94 (yellow spheres), which are supposed to be involved in gB interactions and are directed towards a model of prefusion $\mathrm{gB}$. The interaction of the tripartite complex $\mathrm{gH} / \mathrm{gL} / \mathrm{gp} 42$ with $\mathrm{gB}$ triggers the conformational transition to postfusion $\mathrm{gB}$, which drives fusion with $B$ cell membranes. The structural view of EBV $\mathrm{gH} / \mathrm{gL}$ shows the disulfide bonds (orange spheres), gp42-binding region (blue spheres) and the KGD-motif (red spheres). TM is transmembrane region, $\alpha$ is $\alpha$-helix and $\beta$ is $\beta$-strand. The protein secondary structure prediction for the CTDs of EBV $\mathrm{gB}$ and $\mathrm{gH}$ were designed using JPred4 (Drozdetskiy et al., 2015). The structural views of prefusion and postfusion gB (PDB ID: 3FVC) (Backovic et al., 2009) as well as the complex composed of $\mathrm{gH} / \mathrm{gL}$ (3PHF) (Matsuura et al., 2010) and gp42-HLA-DR1 (1KG0) (Mullen et al., 2002; Sathiyamoorthy et al., 2014) were generated using The PyMOL Molecular Graphics System, Version 1.3 Schrödinger, LLC.

thelial cells (Tugizov et al., 2003). Whereas binding of gp42 to its $B$ cell receptor human leukocyte antigen (HLA) class II activates $\mathrm{gH} / \mathrm{gL}$, which in turn triggers gB-mediated membrane fusion (Fig. 1), the gp42 interaction with $\mathrm{gH} / \mathrm{gL}$ blocks epithelial cell fusion and entry (Borza and Hutt-Fletcher, 2002; Chen et 2012). Thus, the highly adapted tropism of EBV is established by the prevalence of either the heterodimeric complex $\mathrm{gH} / \mathrm{gL}$ or the tripartite complex $\mathrm{gH} / \mathrm{gL} / \mathrm{gp} 42$ on EBV virions. For virus produced in B cells, HLA class II regulates the amount of gp42 on the budding virions by sequestrating it during its maturation pathway, thereby modulating the ratio of the epithelial cell-tropic complex $(\mathrm{gH} / \mathrm{gL})$ and the B cell-tropic complex ( $\mathrm{gH} / \mathrm{gL} / \mathrm{gp} 42)$, reducing the latter. Since epithelial cells lack HLA class II, virions produced from these cells infect $B$ cells more readily since they are enriched in the tripartite $\mathrm{gH} / \mathrm{gL} / \mathrm{gp} 42$ complex essential for B cell infection (Borza and Hutt-Fletcher, 2002; Wang et al., 1998). The receptor-binding activation step is initiated by either the interaction of $\mathrm{gH}$ with integrins such as $\alpha v \beta 5, \alpha v \beta 6$ or $\alpha v \beta 8$ on epithelial cells (Fig. 2) or binding of gp42 to its B cell receptor HLA class II. It is likely that this receptor-binding event activates $\mathrm{gH} / \mathrm{gL}$ to interact with $\mathrm{gB}$ in a homotypic manner (EBV $\mathrm{gH} / \mathrm{gL}$ can trigger only $\mathrm{EBV} \mathrm{gB}$ ), triggering the conformational change to the postfusion form of $\mathrm{gB}$ and thereby mediating fusion (Fig. 1-2) (Connolly et al., 2011; Stampfer and Heldwein, 2012).

\section{STRUCTURAL FEATURES OF THE CORE ENTRY MACHINERY}

The crystal structures for the core fusion machinery consisting of $\mathrm{gB}, \mathrm{gH} / \mathrm{gL}$ and gp42 shed light on the herpesvirus-induced membrane fusion process.

\section{Structural features of the fusogen $g B$}

The crystal structure of EBV gB in its post-fusion conformation, with its fusion peptides close to its transmembrane domains, revealed $16 \mathrm{~nm}$ spike-like homotrimers formed by individual subunits that adopt an elongated conformation divided into five domains. The similarity to the postfusion conformation of the vesicular stomatitis virus $G$ protein, along with other structural features that distinguish these proteins from previously established class I and II viral fusogens, led to their new classification as class III viral fusion proteins (Backovic et al., 2009; Heldwein et al., 2006; Roche et al., 2006; Steven and Spear, 2006). HSV-1, human cytomegalovirus (HCMV) and EBV gB share strikingly similar postfusion structures but the diverse domain orientations suggest species-specific functional adaptations for the EBV glycoproteins (Backovic et al., 2009; Burke and Heldwein, 2015; Chandramouli et al., 2015; Heldwein et al., 2006). Moreover, the crystal structure revealed that the trimeric form of $\mathrm{gB}$ features a long $\mathrm{C}$-terminal arm, which is arranged in an antiparallel orientation to the coiled-coil core (Backovic et al., 2009; Connolly and Longnecker, 2012). A functional study of HSV $\mathrm{gB}$ showed that this arm-region is important for fusion suggesting that the formation of the coil-arm complex mediates the conformational change to the postfusion form of $\mathrm{gB}$ simito class I fusogens (Connolly and Longnecker, 2012). Surprisingly, the hydrophobic fusion loops of EBV $\mathrm{gB}$, which are typical features of class $\mathrm{I} / \mathrm{Il}$ viral fusogens, cannot be exchanged with the more hydrophilic fusion loops of HSV $\mathrm{gB}$. Further, it has been noted that there is a virus-specific correlation between the hydrophobicity of the $\mathrm{gB}$ fusion loops and membrane proximal region (Backovic et al., 2007a; 2007b; Zago et al., 2012). 


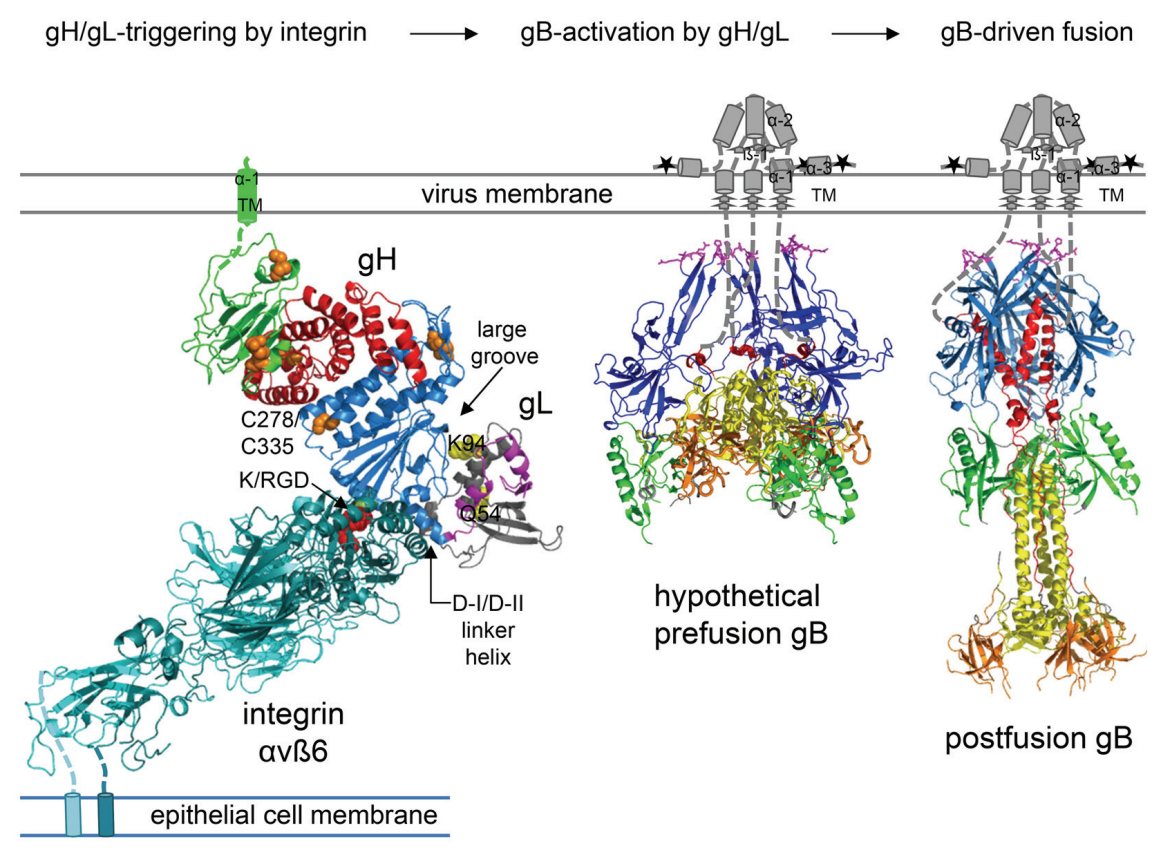

Fig. 2. Model of EBV entry into epithelial cells. First, $\mathrm{gH}$ binds to its epithelial cell receptor integrin $\alpha v \beta 6$ causing a conformational change within the large groove of $\mathrm{gH} / \mathrm{gL}$, which might allow the interaction with the fusogen $\mathrm{gB}$. This interaction triggers the conformational transition to postfusion $\mathrm{gB}$, which drives fusion with the plasma membrane. The K/RGD-motif was used to model integrin binding to $\mathrm{gH} / \mathrm{gL}$ based on the structure of $\alpha v \beta 6 / T G F-\beta 3$ (4UM9). The structural views of integrin $\alpha v \beta 6$ (4UM9) (Dong et al., 2014), prefusion and postfusion gB (3FVC) (Backovic et al., 2009) were generated using The PyMOL Molecular Graphics System, Version 1.3 Schrödinger, LLC.
Structural features of the heterodimeric complex $\mathrm{gH} / \mathrm{gL}$ The structures of EBV, HSV-2 and VZV gH/gL as well as pseudorabies virus (PrV) $\mathrm{gH}$ indicated that $\mathrm{gH} / \mathrm{gL}$ has no features in common with known fusogens (Backovic et al., 2010; Chowdary et al., 2010; Matsuura et al., 2010; Xing et al., 2015). EBV $\mathrm{gH} / \mathrm{gL}$ and $\mathrm{PrV} \mathrm{gH}$ are characterized by an elongated rodlike shape, whereas HSV-2 and VZV $\mathrm{gH} / \mathrm{gL}$ have a boot-like overall conformation (Backovic et al., 2010; Chowdary et al., 2010; Matsuura et al., 2010). The strikingly similar structure of $\mathrm{gH} / \mathrm{gL}$, despite the low amino acid conservation, led to the partition into four structural domains with varied domain interfaces due to divergent inter-domain packing angles (Backovic et al., 2010; Matsuura et al., 2010). Mutagenesis studies of EBV and $\mathrm{PrV} \mathrm{gH}$ found that these domain interfaces and their flexibility are important for $\mathrm{gH} / \mathrm{gL}$ function during fusion (Böhm et al., 2015; Chen et al., 2013; Möhl et al., 2015; Wu et al., 2005). The intimate interaction of $\mathrm{gL}$ with the $\mathrm{N}$-terminus of $\mathrm{gH}$ forms domain I (D-I) and only a single helix, known as the D-I/D-II-linkerhelix, connects $\mathrm{D}-\mathrm{I}$ with the rest of $\mathrm{gH}$ forming a large interdomain groove (Matsuura et al., 2010). Interestingly, an alanine-scanning mutagenesis approach indicates that the linkerhelix is important for gB-mediated fusion with both epithelial and $B$ cells (Figs. 1 and 2) (Omerovic et al., 2005). The $\mathrm{gH}$ homologs feature a striking pattern of disulfide bonds (DB) distributed over the surface of $\mathrm{gH}$, except for one unpaired cysteine (C153) in the large D-I/D-II-groove. The highly conserved DB of D-III is buried suggesting a stabilizing function. Compatible with this hypothesis, we found that this DB forms interactions with surrounding amino acids which ensure the cell surface expression of PrV and EBV $\mathrm{gH} / \mathrm{gL}$ and thus is imfor HSV, PrV and EBV $\mathrm{gH} / \mathrm{gL}$ function during fusion (Cairns et al., 2005; Möhl et al., 2015; Schröter et al., 2014).

\section{Structural features of the tropism determinant gp42}

In contrast to $\mathrm{gB}$ and $\mathrm{gH} / \mathrm{gL}$, the type II single pass membrane protein gp42 is unique to EBV and closely-related lymphocryp- toviruses. The overall structure of gp42 is formed by a C-type lectin domain (CTLD) and a flexible, extended N-terminus extending away from the CTLD, which is tied to the core by a DB (Mullen et al., 2002). Despite the characteristic CTLD within gp42, the HLA class II binding site is distinct from the canonical binding site of lectin and natural killer receptor ligands (Mullen et al., 2002; Spear and Longnecker, 2003). Interestingly, the CTLD contains a hydrophobic pocket at this canonical site, which is located next to the HLA-binding site and experiences a slight conformational change in its loop, widening the pocket after HLA receptor-binding, which could be important for activating entry (Kirschner et al., 2009). The conformational change within the hydrophobic pocket is thought to be involved in activation of the gB-mediated fusion process, but also requires the simultaneously tight binding to $\mathrm{gH} / \mathrm{gL}$ via the flexible N-terminus (residues 36-81) (Kirschner et al., 2007; 2009; Liu et al., 2010; Mullen et al., 2002; Silva et al., 2004).

\section{gH/gL ALSO ACTS AS A DETERMINANT FOR EBV CELL TROPISM}

Besides the presumed role of $\mathrm{gH} / \mathrm{gL}$ in triggering fusion, $\mathrm{gH} / \mathrm{gL}$ is also an important determinant of the cell tropism for some herpesviruses such as EBV (Borza and Hutt-Fletcher, 2002; Chen et al., 2012; Hutt-Fletcher and Chesnokova, 2010; Möhl et al., 2014), HCMV (Adler, 2015; Revello and Gerna, 2010; Zhou et al., 2015) and human herpesvirus 6 (Jasirwan et al., 2014; Mori, 2009; Tang et al., 2014). EBV has evolved specific adaptations for the epithelial and $\mathrm{B}$ cell infection, such as a KGD-motif and the DB C278/C335 of D-II of $\mathrm{gH}$. The bifunctional KGD-binding motif, an exposed loop, enables the competitive binding of $\mathrm{gH}$ to integrins on epithelial cells (Fig. 1) or to gp42, which in turn binds to HLA class II (Fig. 2) (Chen et al., 2012; Hutt-Fletcher and Chesnokova, 2010; Matsuura et al., 2010; Sathiyamoorthy et al., 2014). The exposed DB C278/ C335 functions as an epithelial cell receptor-specific determi- 
nant for the highly-adapted tropism of EBV. This DB tightens the syntaxin-like bundle causing a local rigidity necessary for epithelial cell receptor binding by $\mathrm{gH} / \mathrm{gL}$, whereas a larger perturbation of this region also disrupts the $\mathrm{B}$ cell fusion activity suggesting a disturbance in the formation of the $\mathrm{B}$ cell entry triggering complex facilitated by the interaction of $\mathrm{gH}$ and gp42 (Möhl et al., 2014; Sathiyamoorthy et al., 2014). Compatible with these observations, negative-stain electron microscopy studies of the EBV B cell entry triggering complex composed of $\mathrm{gH} / \mathrm{gL} / \mathrm{gp} 42$ with HLA class II described a distinct binding refor the gp42 CTLD. This gH-binding region is formed by the $D$ II/D-III-interface, defining this as an important site for $\mathrm{gH}$ mediated cell tropism of EBV (Sathiyamoorthy et al., 2014). Previous studies implicated the KGD-motif, which is adjacent to the D-I/D-II-interface, in gp42-binding (Chen et al., 2012; Sathiyamoorthy et al., 2014). Distinct engagement of gp42-binding sites within $\mathrm{gH} / \mathrm{gL}$ may occur to mediate the observed open-closed conformational transition to activate the gB-mediated fusion process. It has been suggested that the binding of $\mathrm{gH} / \mathrm{gL}$ to its epithelial cell receptor integrin causes a conformational change within the large D-I/D-IIgroove (Chesnokova and Hutt-Fletcher, 2011). It is possible that structural rearrangements within the D-I/D-II-interface or even interactions across the large groove are triggered by binding of $\mathrm{gH} / \mathrm{gL}$ to its epithelial cell receptor (Chen et al., 2013; Chesnokova and Hutt-Fletcher, 2011).

\section{INTERACTION OF gB AND $g H / g L$}

It is thought that the $\mathrm{gH} / \mathrm{gL} \mathrm{D}-\mathrm{I}$ and $\mathrm{D}-\mathrm{I} / \mathrm{D}$-II-interface are involved in gB-binding and activation (Plate et al., 2009; Xing et al., 2015). In support of this possibility, a previous study established that the $\mathrm{gL}$ residues glutamine (Q) 54 and lysine (K) 94 are involved in the EBV-specific engagement and activation of $\mathrm{gB}$ by $\mathrm{gH} / \mathrm{gL}$ during herpesvirus fusion due to a species-specific dependence between $\mathrm{gB}$ and $\mathrm{gL}$ (Figs. 1 and 2) (Omerovic and Longnecker, 2007; Plate et al., 2009; 2011). For HSV-1 gH/gL, it was shown that the neutralizing antibody LP11 inhibits $\mathrm{gH} / \mathrm{gL}-$ binding to $\mathrm{gB}$ using bimolecular fluorescence complementation (Chowdary et al., 2010), potentially identifying gB interacting surface. Based on LP11-resistant viruses and insertion mutants that prevent the LP11-binding, the LP11-epitope was mapped to the aspartic acid 168 and arginine 329 , as well as the residues 201-326 (Chowdary et al., 2010; Galdiero et al., 1997; Gompels et al., 1991). The recently published crystal structure of $\mathrm{VZV} \mathrm{gH} / \mathrm{gL}$ revealed that residues corresponding to the $\mathrm{LP11}$-epitope on $\mathrm{HSV} \mathrm{gH} / \mathrm{gL}$ and the gB-binding residues of EBV $\mathrm{gL}$ area also engaged by the neutralizing antibody Fab$\mathrm{RC} / 94$, suggesting that this surface is near the $\mathrm{VZV} \mathrm{gH} / \mathrm{gL}-$ binding site for $\mathrm{gB}$ activation (Xing et al., 2015).

To further map these interactions on $\mathrm{gB}$, the species-specific dependence between $\mathrm{gB}$ and $\mathrm{gL}$ was studied by a panel of chimeric gB proteins of EBV and the closely-related Rh-LCV using bimolecular complementation. These studies indicated that EBV gB residues $450-800$ (corresponding to $456-807$ in Rh-LCV gB) are necessary for binding to $\mathrm{gH} / \mathrm{gL}$ (Plate et al., 2011). The hyperfusogenic EBV gB mutant gB843 showed that the cytoplasmic tail of $\mathrm{gB}$ is not necessary for $\mathrm{gH} / \mathrm{gL}$ binding using proximity ligation assay (Chen et al., 2014). Moreover, it was shown that neutralizing antibodies against the fusion loops of $\mathrm{HSV} \mathrm{gB}$ prevented binding to $\mathrm{gH} / \mathrm{gL}$ using bimolecular complementation. This data suggest that this region, including residues $670-725$, is important for the $\mathrm{gB}-\mathrm{gH} / \mathrm{gL}$-interaction during fusion (Atanasiu et al., 2010). Interestingly, the corresponding region within $\mathrm{HCMV} \mathrm{gB}$ is heavily glycosylated, which suggests a shielding function to prevent immune recognition and neutralization (Burke and Heldwein, 2015).

\section{THE CYTOPLASMIC/INTRAVIRAL DOMAIN OF gB AND $g H / g L$}

While the principal function of the ectodomain of herpesvirus $\mathrm{gH} / \mathrm{gL}$ and $\mathrm{gB}$ is well characterized, the function of the cytoplasmic/intraviral tail domains (CTD) of $\mathrm{gB}$ and $\mathrm{gH} / \mathrm{gL}$ remains incompletely understood. Compared to the CTD of EBV $\mathrm{gH}$, which only has 8 amino acids, gB has a much longer CTD comprising 104 amino acids. Recent findings suggest that the CTD is also involved in keeping $\mathrm{gB}$ in an inactive metastable prefusion state by functioning as a clamp (Chen et al., 2014; Rogalin and Heldwein, 2015). These findings are supported by previous gB mutagenesis studies, which confirm that the CTD of $\mathrm{gB}$ carries distinct regulatory regions involved in virion transport and regulating fusion activity (Garcia et al., 2013; Haan et al., 2001; Lee and Longnecker, 1997). Furthermore, a comprehensive library study of EBV gB CTD truncation mutants explored that the length of the gB tail is not directly related to fusion function (Garcia et al., 2013). Compatible with this observation, the CTD of EBV or HSV gB may regulate the energy requirement for fusion activity (Chen et al., 2014; Rogalin and Heldwein, 2015). Interestingly, the gH CTD differentially regulates the fusion activity among herpesviruses since mutagenesis or deletion studies of HSV and VZV gH indicate that the CTD may positively or negatively regulate fusion function (Harman et al., 2002; Rogalin and Heldwein, 2015; Silverman et al., 2012; Yang et al., 2014). Since the gH tail is very short with close proximity to the membrane, it may function as "inside-out" signal by affecting the extracellular conformation of $\mathrm{gH} / \mathrm{gL}$ as has been reported in fusion proteins of other viruses (Waning et al., 2004). Another function for the CTD of gB is to regulate the trafficking of the protein. $\mathrm{EBV} \mathrm{gB}$ is localized mainly in the endoplasmic reticulum/nuclear membrane with little $\mathrm{gB}$ expression on the plasma membrane or a mature viral particle (Gong and Kieff, 1990).

\section{CONCLUSION}

In summary, the structures are known for all of the essential EBV receptor-binding proteins including $\mathrm{gH} / \mathrm{gL}$ and gp42, as well as postfusion $\mathrm{gB}$. The prefusion structure is not known for $\mathrm{gB}$ for any members of the herpesvirus family. The $\mathrm{B}$ cell entry triggering complex without $\mathrm{gB}$ has been reported (Sathiyamoorthy et al., 2014) and provides a basis for comparison with models of the epithelial cell entry triggering complex. Similarities in the overall architectures for these two triggering complexes further our understanding of how $\mathrm{gH} / \mathrm{gL}$ may activate fusion and provide a basis for designing experiments to examine the interactions required to activate $\mathrm{gB}$.

\section{ACKNOWLEDGMENTS}

The research in the Longnecker and Jardetzky laboratories was supported by the National Institute of Allergy and Infectious Diseases (grant Al076183 to to R.L. and T.S.J.) and by the National Cancer Institute (grant CA117794 to R.L. and T.S.J.), and by a postdoctoral fellowship from the Deutsche Forschungsgemeinschaft DFG (MO2500/1-1 to Britta S. Möhl) as well as by the Chicago Biomedical Consortium (Fall 14-0121 and 15-0257 to Jia Chen). The authors thank current and former members of their laboratories for their contributions to the work described. 


\section{REFERENCES}

Adler, B. (2015). A viral pilot for HCMV navigation? Viruses 7, 38573862.

Atanasiu, D., Whitbeck, J.C., de Leon, M.P., Lou, H., Hannah, B.P., Cohen, G.H., and Eisenberg, R.J. (2010). Bimolecular complementation defines functional regions of Herpes simplex virus $\mathrm{gB}$ that are involved with $\mathrm{gH} / \mathrm{gL}$ as a necessary step leading to cell fusion. J. Virol. 84, 3825-3834.

Backovic, M., Jardetzky, T.S., and Longnecker, R. (2007a). Hydrophobic residues that form putative fusion loops of EpsteinBarr virus glycoprotein $\mathrm{B}$ are critical for fusion activity. J. Virol. 81, 9596-9600.

Backovic, M., Leser, G.P., Lamb, R.A., Longnecker, R., and Jardetzky, T.S. (2007b). Characterization of EBV gB indicates properties of both class I and class II viral fusion proteins. Virology 368, 102-113.

Backovic, M., Longnecker, R., and Jardetzky, T.S. (2009). Structure of a trimeric variant of the Epstein-Barr virus glycoprotein B. Proc. Natl. Acad. Sci. USA 106, 2880-2885.

Backovic, M., DuBois, R.M., Cockburn, J.J., Sharff, A.J., Vaney, M.C., Granzow, H., Klupp, B.G., Bricogne, G., Mettenleiter, T.C., and Rey, F.A. (2010). Structure of a core fragment of glycoprotein $\mathrm{H}$ from pseudorabies virus in complex with antibody. Proc. Natl. Acad. Sci. USA 107, 22635-22640.

Böhm, S.W., Eckroth, E., Backovic, M., Klupp, B.G., Rey, F.A., Mettenleiter, T.C., and Fuchs, W. (2015). Structure-based functional analyses of domains II and III of pseudorabies virus glycoprotein H. J. Virol. 89, 1364-1376.

Borza, C.M., and Hutt-Fletcher, L.M. (2002). Alternate replication in $B$ cells and epithelial cells switches tropism of Epstein-Barr virus. Nat. Med. 8, 594-599.

Burke, H.G., and Heldwein, E.E. (2015). Crystal structure of the human cytomegalovirus Glycoprotein B. PLoS Pathog. 11, e1005227.

Cairns, T.M., Landsburg, D.J., Whitbeck, J.C., Eisenberg, R.J., and Cohen, G.H. (2005). Contribution of cysteine residues to the structure and function of herpes simplex virus $\mathrm{gH} / \mathrm{gL}$. Virology 332, 550-562.

Chandramouli, S., Ciferri, C., Nikitin, P.A., Calo, S., Gerrein, R., Balabanis, K., Monroe, J., Hebner, C., Lilja, A.E., Settembre, E.C., et al. (2015). Structure of HCMV glycoprotein B in the postfusion conformation bound to a neutralizing human antibody. Nat. Commun. 6, 8176.

Chen, J., Rowe, C.L., Jardetzky, T.S., and Longnecker, R. (2012). The KGD motif of Epstein-Barr virus $\mathrm{gH} / \mathrm{gL}$ is bifunctional, orchestrating infection of $\mathrm{B}$ cells and epithelial cells. MBio 3, pii: e00290-11.

Chen, J., Jardetzky, T.S., and Longnecker, R. (2013). The large groove found in the $\mathrm{gH} / \mathrm{gL}$ structure is an important functional domain for Epstein-Barr virus fusion. J. Virol. 87, 3620-3627.

Chen, J., Zhang, X., Jardetzky, T.S., and Longnecker, R. (2014). The Epstein-Barr virus (EBV) glycoprotein B cytoplasmic Cterminal tail domain regulates the energy requirement for EBVinduced membrane fusion. J. Virol. 88, 11686-11695.

Chesnokova, L.S., and Hutt-Fletcher, L.M. (2011). Fusion of Epstein-Barr virus with epithelial cells can be triggered by alphavbeta5 in addition to alphavbeta6 and alphavbeta8, and integrin binding triggers a conformational change in glycoproteins gHgL. J. Virol. 85, 13214-13223.

Chowdary, T.K., Cairns, T.M., Atanasiu, D., Cohen, G.H., Eisenberg, R.J., and Heldwein, E.E. (2010). Crystal structure of the conserved herpesvirus fusion regulator complex $\mathrm{gH}-\mathrm{gL}$. Nat. Struct. Mol. Biol. 17, 882-888.

Connolly, S.A., Jackson, J.O., Jardetzky, T.S., and Longnecker, R. (2011). Fusing structure and function: a structural view of the herpesvirus entry machinery. Nat Rev Microbiol 9, 369-381.

Dong, X., Hudson, N.E., Lu, C., and Springer, T.A. (2014). Structural determinants of integrin beta-subunit specificity for latent TGF-beta. Nat. Struct. Mol. Biol. 21, 1091-1096.

Drozdetskiy, A., Cole, C., Procter, J., and Barton, G.J. (2015). JPred4: a protein secondary structure prediction server. Nucleic Acids Res. 43, W389-394.

Galdiero, M., Whiteley, A., Bruun, B., Bell, S., Minson, T., and Browne, H. (1997). Site-directed and linker insertion mutagenesis of herpes simplex virus type 1 glycoprotein H. J. Virol. 71, 2163-
2170.

Garcia, N.J., Chen, J., and Longnecker, R. (2013). Modulation of Epstein-Barr virus glycoprotein $\mathrm{B}(\mathrm{gB})$ fusion activity by the $\mathrm{gB}$ cytoplasmic tail domain. MBio 4, e00571-00512.

Gompels, U.A., Carss, A.L., Saxby, C., Hancock, D.C., Forrester, A. and Minson, A.C. (1991). Characterization and sequence analyses of antibody-selected antigenic variants of herpes simplex virus show a conformationally complex epitope on glycoprotein H. J. Virol. 65, 2393-2401.

Gong, M., and Kieff, E. (1990). Intracellular trafficking of two major Epstein-Barr virus glycoproteins, gp350/220 and gp110. J. Virol. 64, 1507-1516.

Haan, K.M., Lee, S.K., and Longnecker, R. (2001). Different functional domains in the cytoplasmic tail of glycoprotein B are involved in Epstein-Barr virus-induced membrane fusion. Virology 290, 106-114.

Harman, A., Browne, H., and Minson, T. (2002). The transmembrane domain and cytoplasmic tail of herpes simplex virus type 1 glycoprotein $\mathrm{H}$ play a role in membrane fusion. $\mathrm{J}$. Virol. 76, 10708-10716.

Heldwein, E.E., Lou, H., Bender, F.C., Cohen, G.H., Eisenberg, R.J., and Harrison, S.C. (2006). Crystal structure of glycoprotein B from herpes simplex virus 1. Science 313, 217-220.

Hutt-Fletcher, L.M., and Chesnokova, L.S. (2010). Integrins as triggers of Epstein-Barr virus fusion and epithelial cell infection. Virulence 1, 395-398.

Janz, A., Oezel, M., Kurzeder, C., Mautner, J., Pich, D., Kost, M., Hammerschmidt, W., and Delecluse, H.J. (2000). Infectious Epstein-Barr virus lacking major glycoprotein BLLF1 (gp350/220) demonstrates the existence of additional viral ligands. J. Virol. 74, 10142-10152.

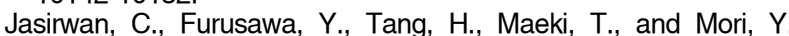
(2014). Human herpesvirus-6A gQ1 and gQ2 are critical for human CD46 usage. Microbiol. Immunol. 58, 22-30.

Kirschner, A.N., Lowrey, A.S., Longnecker, R., and Jardetzky, T.S. (2007). Binding-site interactions between Epstein-Barr virus fusion proteins $\mathrm{gp} 42$ and $\mathrm{gH} / \mathrm{gL}$ reveal a peptide that inhibits both epithelial and B-cell membrane fusion. J. Virol. 81, 9216-9229.

Kirschner, A.N., Sorem, J., Longnecker, R., and Jardetzky, T.S. (2009). Structure of Epstein-Barr virus glycoprotein 42 suggests a mechanism for triggering receptor-activated virus entry. Structure 17, 223-233.

Langeland, N., Oyan, A.M., Marsden, H.S., Cross, A., Glorioso, J.C. Moore, L.J., and Haarr, L. (1990). Localization on the herpes simplex virus type 1 genome of a region encoding proteins involved in adsorption to the cellular receptor. J. Virol. 64, 12711277.

Lee, S.K., and Longnecker, R. (1997). The Epstein-Barr virus glycoprotein 110 carboxy-terminal tail domain is essential for lytic virus replication. J. Virol. 71, 4092-4097.

Liu, F., Marquardt, G., Kirschner, A.N., Longnecker, R., and Jardetzky, T.S. (2010). Mapping the $\mathrm{N}$-terminal residues of Epstein-Barr virus gp42 that bind $\mathrm{gH} / \mathrm{gL}$ by using fluorescence polarization and cell-based fusion assays. J. Virol. 84, 1037510385.

Longnecker, R., Kieff, E., and Cohen, J. (2013). Epstein-Barr virus, 6th eds. (Philadelphia, PA, Lippincott, Wilkins, and Williams)

Matsuura, H., Kirschner, A.N., Longnecker, R., and Jardetzky, T.S. (2010). Crystal structure of the Epstein-Barr virus (EBV) glycoprotein $\mathrm{H} / \mathrm{glycoprotein} \mathrm{L}(\mathrm{gH} / \mathrm{gL})$ complex. Proc. Natl. Acad. Sci. USA 107, 22641-22646.

Miller, N., and Hutt-Fletcher, L.M. (1992). Epstein-Barr virus enters B cells and epithelial cells by different routes. J. Virol. 66, 34093414.

Möhl, B.S., Sathiyamoorthy, K., Jardetzky, T.S., and Longnecker, R (2014). The conserved disulfide bond within domain II (D-II) of Epstein-Barr virus (EBV) $\mathrm{gH}$ has divergent roles in membrane fusion with epithelial cells and B cells. J. Virol. 88, 13570-13579.

Möhl, B.S., Schröter, C., Klupp, B.G., Fuchs, W., Mettenleiter, T.C., Jardetzky, T.S., and Longnecker, R. (2015). Comparative mutagenesis of Pseudorabies and Epstein-Barr virus $\mathrm{gH}$ identifies a structural determinant within domain III of $\mathrm{gH}$ required for surface expression and entry function. J. Virol. 90, 2285-2293.

Mori, Y. (2009). Recent topics related to human herpesvirus 6 cell tropism. Cell Microbiol. 11, 1001-1006.

Mullen, M.M., Haan, K.M., Longnecker, R., and Jardetzky, T.S. 
(2002). Structure of the Epstein-Barr virus gp42 protein bound to the MHC class II receptor HLA-DR1. Mol. Cell 9, 375-385.

Nemerow, G.R., and Cooper, N.R. (1984). Early events in the infection of human B lymphocytes by Epstein-Barr virus: the internalization process. Virology 132, 186-198.

Ogembo, J.G., Kannan, L., Ghiran, I., Nicholson-Weller, A., Finberg, R.W., Tsokos, G.C., and Fingeroth, J.D. (2013). Human complement receptor type 1/CD35 is an Epstein-Barr Virus receptor. Cell Rep. 3, 371-385.

Omerovic, J., and Longnecker, R. (2007). Functional homology of $\mathrm{gHs}$ and gLs from EBV-related gamma-herpesviruses for EBVinduced membrane fusion. Virology 365, 157-165.

Omerovic, J., Lev, L., and Longnecker, R. (2005). The amino terminus of Epstein-Barr virus glycoprotein $\mathrm{gH}$ is important for fusion with epithelial and B cells. J. Virol. 79, 12408-12415.

Plate, A.E., Smajlovic, J., Jardetzky, T.S., and Longnecker, R. (2009). Functional analysis of glycoprotein $\mathrm{L}(\mathrm{gL})$ from rhesus lymphocryptovirus in Epstein-Barr virus-mediated cell fusion indicates a direct role of $\mathrm{gL}$ in $\mathrm{gB}$-induced membrane fusion. $\mathrm{J}$. Virol. 83, 7678-7689.

Plate, A.E., Reimer, J.J., Jardetzky, T.S., and Longnecker, R. (2011). Mapping regions of Epstein-Barr virus (EBV) glycoprotein $\mathrm{B}(\mathrm{gB})$ important for fusion function with $\mathrm{gH} / \mathrm{gL}$. Virology $413,26-$ 38.

Revello, M.G., and Gerna, G. (2010). Human cytomegalovirus tropism for endothelial/epithelial cells: scientific background and clinical implications. Rev. Med. Virol. 20, 136-155

Roche, S., Bressanelli, S., Rey, F.A., and Gaudin, Y. (2006). Crystal structure of the low-pH form of the vesicular stomatitis virus glycoprotein G. Science 313, 187-191.

Rogalin, H.B., and Heldwein, E.E. (2015). Interplay between the herpes simplex virus $1 \mathrm{gB}$ cytodomain and the $\mathrm{gH}$ cytotail during cell-cell fusion. J. Virol. 89, 12262-12272.

Sathiyamoorthy, K., Jiang, J., Hu, Y.X., Rowe, C.L., Möhl, B.S., Chen, J., Jiang, W., Mellins, E.D., Longnecker, R., Zhou, Z.H., et al. (2014). Assembly and architecture of the EBV B cell entry triggering complex. PLoS Pathog. 10, e1004309.

Schröter, C., Klupp, B.G., Fuchs, W., Gerhard, M., Backovic, M., Rey, F.A., and Mettenleiter, T.C. (2014). The highly conserved proline at position 438 in Pseudorabies Virus $\mathrm{gH}$ is important for regulation of membrane fusion. J. Virol. 88, 13064-13072.

Silva, A.L., Omerovic, J., Jardetzky, T.S., and Longnecker, R. (2004). Mutational analyses of Epstein-Barr virus glycoprotein 42 reveal functional domains not involved in receptor binding but required for membrane fusion. J. Virol. 78, 5946-5956.

Silverman, J.L., Greene, N.G., King, D.S., and Heldwein, E.E.
(2012). Membrane requirement for folding of the herpes simplex virus $1 \mathrm{gB}$ cytodomain suggests a unique mechanism of fusion regulation. J. Virol. 86, 8171-8184.

Spear, P.G., and Longnecker, R. (2003). Herpesvirus entry: an update. J. Virol. 77, 10179-10185.

Stampfer, S.D., and Heldwein, E.E. (2012). Stuck in the middle: structural insights into the role of the $\mathrm{gH} / \mathrm{gL}$ heterodimer in herpesvirus entry. Curr. Opin. Virol. 3, 13-19.

Steven, A.C., and Spear, P.G. (2006). Biochemistry. Viral glycoproteins and an evolutionary conundrum. Science 313, 177178.

Tang, H., Wang, J., Mahmoud, N.F., and Mori, Y. (2014). Detailed study of the interaction between human herpesvirus 6B glycoprotein complex and its cellular receptor, human CD134. J. Virol. 88, 10875-10882.

Tugizov, S.M., Berline, J.W., and Palefsky, J.M. (2003). EpsteinBarr virus infection of polarized tongue and nasopharyngeal epithelial cells. Nat. Med. 9, 307-314.

Wang, X., Kenyon, W.J., Li, Q., Mullberg, J., and Hutt-Fletcher, L.M (1998). Epstein-Barr virus uses different complexes of glycoproteins $\mathrm{gH}$ and $\mathrm{gL}$ to infect $\mathrm{B}$ lymphocytes and epithelial cells. J. Virol. 72, 5552-5558.

Waning, D.L., Russell, C.J., Jardetzky, T.S., and Lamb, R.A. (2004) Activation of a paramyxovirus fusion protein is modulated by inside-out signaling from the cytoplasmic tail. Proc. Natl. Acad. Sci. USA 101, 9217-9222.

Wu, L., Borza, C.M., and Hutt-Fletcher, L.M. (2005). Mutations of Epstein-Barr virus $\mathrm{gH}$ that are differentially able to support fusion with B cells or epithelial cells. J. Virol. 79, 10923-10930.

Xing, Y., Oliver, S.L., Nguyen, T., Ciferri, C., Nandi, A., Hickman, J., Giovani, C., Yang, E., Palladino, G., Grose, C., et al. (2015). A site of varicella-zoster virus vulnerability identified by structural studies of neutralizing antibodies bound to the glycoprotein complex gHgL. Proc. Natl. Acad. Sci. USA 112, 6056-6061.

Yang, E., Arvin, A.M., and Oliver, S.L. (2014). The cytoplasmic domain of varicella-zoster virus glycoprotein $\mathrm{H}$ regulates syncytia formation and skin pathogenesis. PLoS Pathog. 10, e1004173.

Zago, A., Connolly, S.A., Spear, P.G., and Longnecker, R. (2012). The fusion loops and membrane proximal region of Epstein-Barr virus glycoprotein $\mathrm{B}(\mathrm{gB})$ can function in the context of herpes simplex virus $1 \mathrm{gB}$ when substituted individually but not in combination. Virus Res. 171, 227-230.

Zhou, M., Lanchy, J.M., and Ryckman, B.J. (2015). Human cytomegalovirus $\mathrm{gH} / \mathrm{gL} / \mathrm{gO}$ promotes the fusion step of entry into all cell types, whereas gH/gL/UL128-131 broadens virus tropism through a distinct mechanism. J. Virol. 89, 8999-9009. 